\title{
FREE IMMUNOGLOBULIN LIGHT CHAINS IN CONNECTIVE TISSUE DISEASES*
}

\author{
BY \\ AMIEL COOPER $†$ AND RODNEY BLUESTONE \\ M.R.C. Group for the Study of Haemolytic Mechanisms, Royal Postgraduate Medical School, London, and Department \\ of Medicine, Hammersmith Hospital, London
}

The basic immunoglobulin subunit consists of two heavy and two light chains held together by covalent disulphide bonds. In most cases of myeloma and Waldenström's disease there is an excess synthesis of light over heavy chains, resulting in Bence Jones proteinaemia and proteinuria. Furthermore, in some cases ("light chain disease"), there is absence of detectable heavy chain synthesis, and the only abnormal proteins detected are Bence Jones light chains (Williams, Brunning, and Wollheim, 1966). Free light chains, believed to be qualitatively similar to Bence Jones light chains, have been detected in very small amounts in normal serum and urine (Berggård, 1961; Stevenson, 1960). Recently, Epstein and Tan (1966) have identified increased amounts of free light chains in the sera, urine, and synovial fluids of some patients with systemic lupus erythematosus and rheumatoid arthritis. We have studied the incidence of free light chains in a large group of patients with connective tissue and allied disorders and have quantitated the light chains in some of these cases using the radial immunodiffusion method. In addition, we have purified the free light chains from the urine of one of the patients with systemic lupus and have shown by starch gel electrophoresis that they are very heterogeneous.

\section{Patients Studied}

\section{Material and Methods}

Serum was obtained from 33 patients with systemic lupus erythematosus, nine with discoid lupus, 41 with rheumatoid arthritis, eleven with ankylosing spondylitis, fourteen with systemic sclerosis (scleroderma), seven with gout, and five with allergic disorders (erythema nodosum (3), Henoch-Schönlein purpura (1), and severe drug reaction (1)). Urine samples were obtained from most of these patients. Synovial fluid samples were aspirated from effusions of 27 of the patients with

\footnotetext{
*Given at a meeting of the Heberden Society on March 22, 1968. †Requests for reprints to L.-Cdr. A. G. Cooper, Blood Research, Naval Hospital, Chelsea, Mass., U.S.A.
}

rheumatoid arthritis, four with ankylosing spondylitis, three with systemic lupus, one with gout, and four with osteoarthrosis. In addition, one sample of pleural fluid and one sample of pericardial fluid were obtained from patients with rheumatoid effusions. The age, sex, duration, and severity of the disease, therapy, and the presence of renal disease or proterinuria were noted for each patient. Serological tests included sheep cell agglutination and latex-fixation tests in the cases of rheumatoid arthritis and ankylosing spondylitis, and antinuclear factor and lupus erythematosus factor tests, and direct Coombs's tests in the cases of systemic lupus.

Control Samples.-These included 36 sera and ten samples of urine from laboratory workers and eighteen post mortem synovial fluids, an attempt being made to exclude patients with a disease likely to affect immunoglobulin metabolism.

\section{Anti-Free Light Chain Sera}

Rabbit antisera specific for free human immunoglobulin light chains were prepared by the method of Tan and Epstein (1965). Rabbits were immunized with free light chains prepared from pooled normal IgG. The resulting antisera were absorbed with normal IgG to remove antibodies against antigens available on light chains bound to heavy chains, leaving only antibodies against antigens exposed on free light chains. The most potent antiserum was used for detection and quantitation of free light chains. The serum, urine, and synovial fluid samples were screened for the presence of free light chains by the immunodiffusion method (Ouchterlony, 1953). The antiserum was shown to be capable of reacting with as little as $1.5 \mathrm{mg}$. per cent. of normal light chains.

The antiserum was rendered type specific for free kappa and free lambda light chains by absorption with a lambda and a kappa Bence Jones light chain, respectively. These two type-specific antisera were used to quantitate the amount of free kappa and of free lambda light chains in those samples shown to be positive in the screening test. The quantitation was performed by the radial immunodiffusion technique (Mancini, Carbonara, and Heremans, 1965), incorporating the antisera into agar 
plates and then placing the samples and appropriate Bence Jones standards into wells cut in the agar. Each sample was tested in a kappa plate, a lambda plate, and a control plate containing only normal unimmunized rabbit serum, in order to exclude non-specific rings. The concentration of free kappa and free lambda assigned to each sample was determined from their precipitin ring diameters by referring to the standard Bence Jones curves. No value was assigned when the precipitin ring was smaller than that of the lowest standard found to be accurately measurable $(1 \cdot 3 \mathrm{mg}$. per cent. for the lambda and $2 \cdot 0 \mathrm{mg}$. per cent. for the kappa).

\section{Demonstration of the Specificity of the Anti-free Light Chain Serum}

Sephadex G-200 gel filtration (Flodin and Killander, 1962) was performed on a sample of synovial fluid from a patient with ankylosing spondylitis giving a strong positive reaction with the anti-free light chain serum. 5-ml. fractions were taken and the protein concentrations were determined from the optical densities at $280 \mathrm{~m} \mu$. Every third tube was concentrated and tested with the anti-free light chain serum and also with antisera specific for $\operatorname{IgM}, \operatorname{IgA}, \operatorname{IgG}$, and albumin (Beringwerke, AG, Marburg-Lahn, Germany). Fig. 1 demonstrates that the intact immunoglobulins (IgM, IgA, IgG) emerged from the column in the initial and middle portions of the protein peak and the albumin emerged later, in keeping
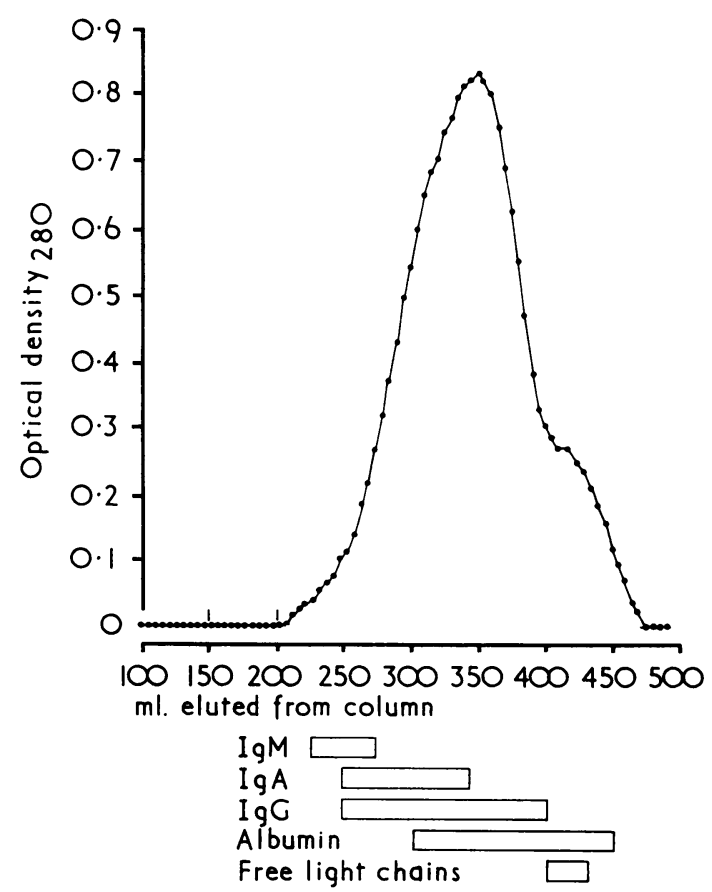

Fig. 1.-Sephadex G-200 filtration of synovial fluid from a patient with ankylosing spondylitis. The location of the various proteins in the effluent was determined by Ouchterlony immunodiffusion using specific antisera. with its smaller molecular weight. The antiserum against free light chains reacted only with the fractions from the terminal portion of the peak, where small molecular weight free light chains would be expected to emerge, and did not react with earlier samples known to contain bound light chains.

\section{Starch Gel Electrophoresis}

The free light chains from a 24-hour urine collection of a patient with systemic lupus were purified by ammonium sulphate precipitation, Sephadex G-200 gel filtration, and finally Sephadex G-100 gel filtration (Baglioni, La Via, and Ventruto, 1965). Alkaline urea starch gel electrophoresis (Cohen and Porter, 1964) was performed on these purified free light chains and also on light chains prepared from normal IgG and on light chains from a purified high titre cold autoantibody (Cooper, 1968).

\section{Results}

Detection and Quantitation of Free Light Chains (see Table, opposite)

Controls.-None of 36 normal sera or ten normal urines gave detectable amounts of free light chains. Two of eighteen post mortem synovial samples contained detectable free light chains, one from aô patient who died of septicaemia and the other from a patient who died 24 hours after cardia surgery. However, neither of these two samples contained sufficient free light chains to be quantitatable.

Systemic Lupus Erythematosus.-Free light chains were detected in the serum of fourteen of 33 patients with systemic lupus. Seven of the fourteen positives were quantitatable for free kappa light chains, but not for free lambda light chains, giving a range of from 2.5 to $11.0 \mathrm{mg}$. per cent. Free light chains were detectable in thirteen out of seventeen urine samples tested and were quantitatable in ten of these samples, ranging from $3 \cdot 1$ to $32 \cdot 4 \mathrm{mg}$. per cent. total. The kappa-lambda ratios ranged from $1 \cdot 1$ to $5 \cdot 6$. Those patients with increased free light chains in the serum invariably had increased free light chains in the urine when this was tested. However, some patients had increased urinary free light chains in the absence of detectable serum free light chains. Two of three synovial effusions tested had detectable amounts of free light chains, but only one had amounts great enough to be quantitated, $3.5 \mathrm{mg}$. per cent. of free kappa and $5 \mathrm{mg}$. per cent. of free lambda. Free light chains were not detected in the serum or urine of this patient.

There was no correlation between the occurrence or severity of renal disease and the incidence of 
TABLE

INCIDENCE AND QUANTITATION OF FREF, LIGHT CHAINS

\begin{tabular}{|c|c|c|c|c|c|c|}
\hline \multirow[b]{2}{*}{ Diagnosis } & \multicolumn{2}{|c|}{ Serum } & \multicolumn{2}{|c|}{ Urine } & \multicolumn{2}{|c|}{ Synovial Fluids } \\
\hline & $\begin{array}{c}\text { Incidence of } \\
\text { free light chains }\end{array}$ & $\begin{array}{l}\text { Concentration* } \\
\text { (mg. per cent.) }\end{array}$ & $\begin{array}{c}\text { Incidence of } \\
\text { free light chains }\end{array}$ & $\begin{array}{l}\text { Concentration } \\
\text { (mg. per cent.) }\end{array}$ & $\begin{array}{c}\text { Incidence of } \\
\text { free light chains }\end{array}$ & $\begin{array}{l}\text { Concentration } \\
\text { (mg. per cent.) }\end{array}$ \\
\hline $\begin{array}{l}\text { Systemic lupus } \\
\text { erythematosus }\end{array}$ & $14 / 33$ & $2 \cdot 5-11 \cdot 0$ & $13 / 17$ & $3 \cdot 1-32 \cdot 4$ & $2 / 3$ & $8 \cdot 5$ \\
\hline Discoid lupus & $0 / 9$ & 0 & $1 / 6$ & N.Q. & - & - \\
\hline Rheumatoid arthritis & $3 / 41$ & N.Q. & $17 / 36$ & $2 \cdot 5-10 \cdot 6$ & $22 / 27$ & $2 \cdot 8-33 \cdot 8$ \\
\hline Ankylosing spondylitis & $0 / 11$ & 0 & $2 / 8$ & $4 \cdot 5$ & $2 / 4$ & $53 \cdot 0$ \\
\hline Systemic sclerosis & $0 / 14$ & 0 & $1 / 14$ & N.Q. & - & - \\
\hline Gout & $0 / 7$ & 0 & $2 / 7$ & N.Q. & $1 / 1$ & $6 \cdot 8$ \\
\hline Osteoarthrosis & - & - & - & - & $0 / 4$ & 0 \\
\hline Allergic disorders & $3 / 5$ & $3 \cdot 6-3 \cdot 8$ & $4 / 4$ & $3 \cdot 8-7 \cdot 2$ & 一 & 一 \\
\hline Controls & $0 / 36$ & 0 & $0 / 10$ & 0 & $2 / 18$ & N.Q. \\
\hline
\end{tabular}

*Concentration given is the sum of free kappa plus free lambda. N.Q. = Positive samples not quantitatable.

serum or urinary free light chains, but there did appear to be some correlation between the overall severity and activity of the disease and the presence of free light chains. It was possible to perform serial determinations on two patients. One patient was first studied during an acute phase of her illness at which time the total urinary free light chains measured $25.4 \mathrm{mg}$. per cent. The patient improved after increasing the dose of prednisone and commencing immunosuppressive therapy and the urinary free light chains became undetectable. The second patient was first studied during a remisson, at which time her total urinary free light chains were $3.6 \mathrm{mg}$. per cent. The patient developed a flare-up of her disease during pregnancy and the urinary free light chains rose to $23.8 \mathrm{mg}$. per cent. The patient was delivered at 32 weeks gestation and samples of serum and urine obtained from the infant at one day of age were positive for free light chains, the urine containing $4.7 \mathrm{mg}$. per cent. However, control samples from normal and premature infants have not been tested.

All of the patients with systemic lupus had a positive ANF. There was no correlation between the occurrence of free light chains and the presence of autoimmune haemolytic anaemia, a positive direct Coombs test, or a positive L.E. test.

Discoid Lupus.-Free light chains were detected in the serum of none of nine patients and in the urine of only one out of six patients tested. This positive urine had insufficient free light chains to quantitate.
Rheumatoid Arthritis.-Only three of 41 serum samples contained detectable free light chains and none of these were high enough to be quantitated. In contrast, free light chains were found in the urine of seventeen of the 36 patients tested and eleven of the positives could be quantitated, ranging from 2.5 to $10.6 \mathrm{mg}$. per cent. In the eight samples in which both free kappa and free lambda were high enough to quantitate, the kappa-lambda ratios ranged from $1 \cdot 1$ to $4 \cdot 1$. Of the seventeen urines tested, three were from patients having secondary amyloid disease, two of whom were sero-negative, and all three of these had quantitatable urinary free light chains.

Synovial aspirates of knee effusions were obtained from 27 patients and 22 of these contained free light chains. The free light chains were present in sufficient amounts to be quantitated in nineteen of these samples with a total ranging from $2 \cdot 8$ to $33.8 \mathrm{mg}$. per cent. The kappa-lambda ratios ranged from 0.7 to 3.8 in the eleven samples where both were quantitatable. The pleural and the pericardial effusions were both strongly positive, containing 18.6 and $16.8 \mathrm{mg}$. per cent. total free light chains respectively.

There was no significant correlation between the duration or severity of the disease or its treatment and the occurrence of free light chains in the serum, urine, or synovial fluid. Synovial fluid was obtained from only one DAT-negative patient, other than the two patients with amyloid, and this lacked detectable free light chains. There was no correlation between the synovial fluid and the urinary free light chain levels. 
Ankylosing Spondylitis.-Serum obtained from eleven patients, all of whom were sero-negative, lacked detectable free light chains in every case. Two of eight urine samples were positive but only one of these was quantitatable $(4 \cdot 5 \mathrm{mg}$. per cent.) but this patient also had amyloid disease with a nephrotic syndrome. Two of four synovial samples obtained from peripheral joint effusions were positive and one contained the largest amount of free light chain detected in this study $(53 \mathrm{mg}$. per cent., with a kappa-lambda ratio of $1 \cdot 2$ ). This patient had longstanding ankylosing spondylitis with severe knee-joint involvement. His serum and urine lacked detectable free light chains.

Systemic Sclerosis (Scleroderma). - Sera and urines from fourteen patients, nine of whom were ANF positive, lacked detectable free light chains with the exception of one urine sample which was weakly positive.

Gout.-Seven patients were studied and all lacked free light chains in the serum. Two of the seven patients had detectable urinary free light chains but in neither case were the amounts large enough to quantitate. One synovial fluid was obtained from a knee joint with acute synovitis and this contained $6.8 \mathrm{mg}$. per cent. of free light chains (kappa-lambda ratio $2 \cdot 8$ ).

Osteoarthrosis.-Four synovial fluids were obtained and these were all negative for free light chains.

Allergic Disorders.-One of three patients with erythema nodosum had detectable serum and urinary free light chains and one patient had only urinary free light chains. The patient with HenöchSchönlein purpura had free light chains in the serum $(3.6 \mathrm{mg}$. per cent.) and in the urine $(4.6 \mathrm{mg}$. per cent.). The patient with a severe drug reaction, characterized by fever, rash, and malaise, had free light chains in the serum $(3.8 \mathrm{mg}$. per cent.) and in the urine $(7 \cdot 2 \mathrm{mg}$. per cent.) and these disappeared when the symptoms abated.

\section{Starch Gel Electrophoresis of Purified Light Chains}

The free light chains were purified from the urine of a patient with systemic lupus and were shown to contain both kappa and lambda types. Fig. 2 shows that the urea starch gel electrophoresis of these light chains gave multiple bands very similar to those of light chains prepared from pooled normal IgG. For comparison, the light chains of the monoclonal cold agglutinin gave a much more homogeneous banding pattern.

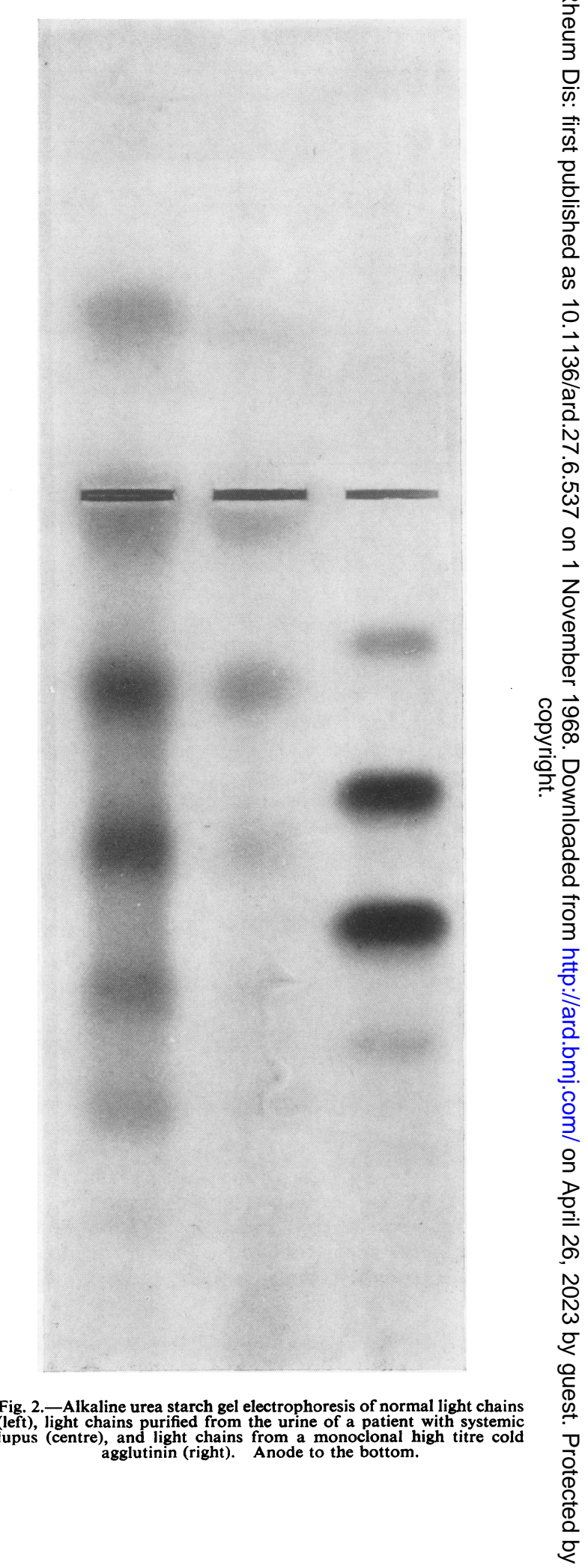




\section{Discussion}

Our results confirm the findings (Epstein and Tan, 1966) of increased free light chains in the serum and urine of patients with systemic lupus erythematosus and in the synovial fluid of patients with rheumatoid arthritis as well as the findings (Gordon, Eisen, and Vaughan, 1966) of increased free light chains in the urine of patients with rheumatoid arthritis. In addition, we have found increased free light chains in the synovial fluids of two out of three patients with systemic lupus, in a rheumatoid pleural and a pericardial effusion, in synovial fluid of some patients with ankylosing spondylitis, and in the serum and urine of patients with allergic disorders. Vaughan, Barnett, and Leadley (1967) have recently reported a case of serum sickness with increase free light chains. Free light chains were undetectable or very low in normal sera and urines, in post mortem synovial fluids, and in patients with discoid lupus, osteoarthrosis, systemic sclerosis, and in gout, with the exception of one acutely inflamed gouty effusion found to have significantly elevated light chains.

The increased free light chains reported here are most probably the result of increased synthesis. Using radioactive amino acid precursors, it has been shown in patients with multiple myeloma (Putnam and Hardy, 1955) and in patients with rheumatoid arthritis and in a normal control (Gordon and others, 1966) that free light chains are synthesized de novo rather than being a breakdown product of intact immunoglobulins. Radioiodinated Bence Jones light chains injected intravenously into normal recipients or myeloma patients without renal insufficiency are metabolised very rapidly, the vast majority being catabolized within the body and approximately 10 per cent. being excreted intact into the urine (Jensen, 1967; Solomon, Waldmann, Fahey, and McFarlane, 1964). From studies in myeloma patients with renal insufficiency (Solomon and others, 1964) and in nephrectomized mice (Wochner, Strober, and Waldmann, 1967) it is believed that the kidney plays a major role in the catabolism of free light chains. In the presence of renal insufficiency, catabolism of light chains is diminished, the concentration of serum free light chains increases, and the amount of free light chains excreted intact into the urine also rises (Epstein, Gulyassy, Tan, and Rae, 1968).

We could find no correlation in our patients with systemic lupus between the free light chain level in the serum or urine and the degree of renal involve- ment. The incidence of increased urinary free light chains in patients with rheumatoid arthritis was higher in those patients also having renal amyloidosis. However, the majority of patients in this study lacked clinically significant renal disease and it is not thought that diminished catabolism played an important role in the increased free light chains reported here.

The diseases in which we have found increased free light chains are those in which an immune mechanism, either autoimmune or allergic, is believed to play a significant role. However, we failed to find increased free light chains in patients with systemic sclerosis, even though there is some evidence of an autoimmune basis of this disease (Beck, Anderson, Gray, and Rowell, 1963).

The synthesis of free light chains has been demonstrated in vitro, using lymph node cell suspensions (Shapiro, Scharff, Maizel, and Uhr, 1966) and cell free extracts of lymph nodes (Vassalli, LassowkaBernstein, Lamm, and Benacerraf, 1967) from immunized animals. It is believed that there is an over-production of light to heavy chains during the synthesis of intact immunoglobulins. This explanation may account for the appearance of free light chains in diseases in which an immune mechanism is playing a role. However, it is not known whether the light chains were produced by cells making antibodies specific to the disease. In this regard, we have also demonstrated free light chains in the serum and urine of a patient with congenital neutropenia, recurrent pyogenic infections, and hypergammaglobulinaemia. No correlation could be made between the incidence of free light chains and the occurrence of specific antibodies such as rheumatoid factor, antinuclear factor, L.E. factor, or erythrocyte autoantibodies. That the free light chains were very heterogeneous was shown by the usual presence of both kappa and lambda subtypes as well as by the demonstration of heterogeneity by starch gel electrophoresis of light chains purified from the urine of a patient with systemic lupus.

Little is known about the sites of synthesis of the free light chains found in our patients. In the patients with rheumatoid arthritis, the light chains were most probably synthesized at sites of inflammation in the synovial membrane or more rarely in the pleural or pericardial membranes. In vitro immunoglobulin synthesis by rheumatoid synovial membranes removed at surgery has recently been reported by Smiley, Sachs, and Ziff, (1968). It is possible that similar methods may be useful in determining the sites of synthesis of free light chains. 


\section{Summary}

Sera, urine, and synovial fluids of patients with connective tissue and allied disorders were examined for the presence of free immunoglobulin light chains. The positive samples were quantitated by the Mancini radial immunodiffusion technique. Large amounts of free light chains were found in the sera and urine of patients with systemic lupus and allergic disorders and in the synovial fluids and urine of patients with rheumatoid arthritis. Free light chains purified from the urine of a patient with systemic lupus were shown by starch gel electrophoresis to be as heterogeneous as pooled normai immunoglobulin light chains.

We wish to thank Prof. J. V. Dacie and Prof. E. G. L. Bywaters for their help and encouragement. We also wish to thank Miss Rebecca Schein for her technical assistance, and Dr. S. Gold, Dr. B. M. Ansell, and Dr. S. M. Worlledge for supplying some of the specimens used in this study. One of us (A.C.) was in part supported by a United States Public Health Service Postdoctoral Research Fellowship (1-F2-A1-8963-01)from the National Institutes of Allergy and Infectious Diseases.

\section{DISCUSSION}

DR. M. THOMPSON (Birmingham): Is there any correlation between the levels of immunoglobulins in the serum and the presence or otherwise of free light chains in the serum and the urine? I think other workers have found that, whenever there is evidence of increased immunoglobulin production in other conditions, evidence of increased free light chains can be found in both serum and urine.

Dr. Bluestone: We have not measured immunoglobulin levels in many of our serum and synovial fluid samples and so cannot correlate them with free light chain levels.

\section{REFERENCES}

Baglioni, C., La Via, M., and Ventruto, V. (1965). Biochim. biophys. Acta, 111, 479 (A study of immunoglobulin structure. I. The fingerprinting of aminoethylated Bence-Jones proteins).

Beck, J. S., Anderson, J. R., Gray, K. G., and Rowell, N. R. (1963). Lancet, 2, 1188 (Antinuclear and precipitating autoantibodies in progressive systemic sclerosis).

Berggård, I. (1961). Clin. chim. Acta, 6, 545 (On a gamma-globulin of low molecular weight in normal human plasma and urine).

Cohen, S., and Porter, R. R. (1964). Biochem. J., 90, 278 (Heterogeneity of the peptide chains of gamma-globulin).

Cooper, A. G. (1968). Clin. exp. Immunol., 3, 691 (Purification of cold agglutinins from patients with chronic cold haemagglutinin disease).

Epstein, W. V., Gulyassy, P. F., Tan, M., and Rae, A. I. (1968). Ann. intern. Med., 68, 48 (Effect of renal homotransplantation on the metabolism of the light chains of immunoglobulins).

- - and Tan, M. (1966). Arthr. and Rheum., 9, 713 (Increase of L-chain proteins in the sera of patients with systemic lupus erythematosus and the synovial fluids of patients with peripheral rheumatoid arthritis).

Flodin, P., and Killander, J. (1962). Biochim. biophys. Acta (Amst.), 63, 403 (Fractionation of human-serum proteins by gel filtration).

Gordon, D. A., Eisen, A. Z., and Vaughan, J. H. (1966). Arthr. and Rheum., 9, 575 (Studies on urinary gamma-globulins in patients with rheumatoid arthritis).

Jensen, K. B. (1967). "Protides of the Biological Fluids", Proc. 14th Coll. Bruges, 1966, ed. H. Peeters, p. 367. Elsevier, Amsterdam. (Metabolism of Bence Jones proteins in nonmyeloma patients).

Mancini, G., Carbonara, A. O., and Heremans, J. F. (1965). Immunochemistry, 2, 235 (Immunochemical quantitation of antigens by single radial immunodiffusion).

Ouchterlony, O. (1953). Acta path. microbiol. scand., 32, 231 (Antigen-antibody reactions in gels).

Putnam, F. W., and Hardy, S. (1955). J. biol. Chem., 212, 361 (Proteins in multiple myeloma. III. Origin of Bence Jones protein).

Shapiro, A. L., Scharff, M. D., Maizel, J. V., and Uhr, J. W. (1966). Nature (Lond.), 211, 243 (Synthesis of excess light chains of gamma globulin by rabbit lymph node cells).

Smiley, J. D., Sachs, C., and Ziff, M. (1968). J. clin. Invest., 47, 624 (In vitro synthesis of immunoglobulin by rheumatoid synovial membrane).

Solomon, A., Waldmann, T. A., Fahey, J. L., and McFarlane, A. S. (1964). Ibid., 43, 103 (Metabolism of Bence Jones Proteins).

Stevenson, G. T. (1960). Ibid.., 39, 1192 (Detection in normal urine of protein resembling Bence Jones protein). 
Tan, M., and Epstein, W. V. (1965). J. Lab. clin. Med., 66, 344 (A direct immunologic assay of human sera for Bence Jones proteins (L-chains) ).

Vassalli, P., Lasowska-Bernstein, B., Lamm, M. E., and Benacerraf, B. (1967). Proc. nat. Acad. Sci., 58, 2422 (Studies on cell-free synthesis of rat immunoglobulins. II. Synthesis of immunoglobulin and of antibody to the dinitrophenyl hapten).

Vaughan, J. H., Barnett, E. V., and Leadley, P. J. (1967). Ann. intern. Med., 67, 596 (Serum sickness: evidence in man of antigen-antibody complexes and free light chains in the circulation during the acute reaction).

Williams, R. C., Brunning, R. D., and Wollheim, F. A. (1966). Ibid., 65, 471 (Light-chain disease. An abortive variant of multiple myeloma).

Wochner, R. D., Strober, W., and Waldmann, T. A. (1967). J. exp. Med., 126, 207 (The role of the kidney in the catabolism of Bence Jones proteins and immunoglobulin fragments).

\section{Chaînes légères libres d'immunoglobuline dans les maladies du tissu conjonctif}

\section{RÉSUMÉ}

On rechercha les chaînes légères libres d'immunoglobuline dans le sérum, l'urine et le liquide synovial des patients atteints de désordres du tissu conjonctif et de maladies associées. On soumit les échantillons positifs à l'analyse quantitative par le procédé d'immunodiffusion radiale de Mancini. On trouva de fortes quantités de chaînes légères libres dans les sérums et dans l'urine des malades atteints de lupus disséminé et de troubles allergiques et dans le liquide synovial et l'urine des malades ayant la polyarthrite rhumatoïde. On montra par l'électrophorèse sur gélose à l'amidon que les chaînes légères libres purifiées provenant de l'urine d'un malade atteint de lupus disséminé sont aussi hétérogènes que les chaînes légères d'immunoglobuline normale du "pool".
Cadenas ligeras libres de inmunoglobulina en las enfermedades del tejido conectivo

\section{Sumario}

Se investigaron las cadenas ligeras libres de inmunoglobulina en el suero, la orina y el líquido sinovial de enfermos con disturbios del tejido conectivo y con afecciones asociadas. Espécimenes positivos fueron sometidos al análisis cuantitativo por el método de inmunodifusión radial de Mancini. Se halló un gran número de cadenas ligeras libres en los sueros y en la orina de enfermos con lupus diseminado y con disturbios alérgicos y en el líquido sinovial y la orina de enfermos con poliartritis reumatoide. Se comprobó por electroforesis sobre gel de almidón que las cadenas ligeras libres purificadas de la orina de un enfermo con lupus diseminado son tan heterogeneas como las cadenas ligeras de inmunoglobulina normal del "pool". 